\title{
Flavonoid compounds of tapak liman plant (Elephantopus scaber) as antihyperuricemia
}

\section{Senyawa flavonoid tanaman tapak liman (Elephantopus scaber) sebagai antihiperurisemia}

\author{
Neni Sri Gunarti ${ }^{1 *}$, Himyatul Hidayah ${ }^{1}$ \\ ${ }^{1}$ Fakultas Farmasi, Universitas Buana Perjuangan Karawang \\ *Corresponding author: neni.gunarti@ubpkarawang.ac.id
}

\begin{abstract}
Background: Hyperuricemia is a condition where uric acid levels in the blood increase more than $6 \mathrm{mg} / \mathrm{dL}$. Tapak liman (Elephantopus scaber) contains flavonoid compounds that are reported to inhibit the activity of the xanthine oxidase enzyme that causes hyperuricemia. Several Asteraceae tribes have activity as antihyperuricemia, one of which is the tapak liman plant (E. scaber) because of the compounds contained in the flavonoid group which has a working mechanism as an inhibitor of the xanthine oxidase enzyme.

Objective: To determine the types of flavonoid compounds in tapak liman (E. scaber) plants that have antihyperuricemic activity.

Method: This research is qualitative research using Literature Review Article (LRA) using Google Scholar, PubMed, ResearchGate, and Science direct databases with keywords related to the research topic, namely "Elephantopus scaber, antihyperuricemia, tapak liman, xanthine oxidase, flavonoids".

Results: Compounds from the flavonoid group in tapak liman that have the potential as antihyperuricemia are luteolin compounds, luteolin-7-glucoside, quercetin, and rutin with the mechanism of inhibiting the activity of the xanthine oxidase enzyme.

Conclusion: compounds from the flavonoid group in tapak liman that have the potential as antihyperuricemic compounds are luteolin, luteolin-7-glucoside, quercetin, and rutin.

Keywords: Elephantopus scaber, antihyperuricemia, tapak liman, xanthine oxidase, flavonoids

\section{Intisari}

Latar belakang: Hiperurisemia merupakan suatu kondisi terjadinya peningkatan kadar asam urat dalam darah lebih dari $6 \mathrm{mg} / \mathrm{dL}$. Tapak liman (E. scaber) mengandung senyawa flavonoid yang dilaporkan dapat menghambat aktivitas enzim xantin oksidase penyebab hiperurisemia. Beberapa suku Asteraceae memiliki aktivitas sebagai antihiperurisemia, salah satunya adalah tanaman tapak liman (E. scaber) karena adanya senyawa yang terkandung yaitu golongan flavonoid yang memiliki mekanisme kerja sebagai inhibitor enzim xanthin oksidase.

Tujuan: Mengetahui jenis-jenis senyawa flavonoid dalam tanaman tapak liman (E. scaber) yang memiliki aktifitas sebagai antihiperurisemia.

Metode: Penelitian ini merupakan penelitian kualitatif menggunakan Literature Review Article (LRA) menggunakan database Google Scholar, PubMed, ResearchGate dan Science direct dengan kata kunci yang berkaitan dengan topik penelitian, yaitu "Elephantopus scaber, antihiperurisemia, tapak liman, xantin oksidase, flavonoid".

Hasil: Senyawa golongan flavonoid pada tapak liman yang berpotensi sebagai antihiperurisemia yaitu senyawa luteolin, luteolin-7-glukosida, kuersetin, dan rutin dengan mekanisme menghambat aktivitas enzim xantin oksidase.
\end{abstract}

Kesimpulan: Senyawa golongan flavonoid pada tapak liman yang berpotensi sebagai antihiperurisemia yaitu senyawa luteolin, luteolin-7-glukosida, kuersetin, dan rutin

Kata kunci : Elephantopus scaber, antihyperuricemia, tapak liman, xanthine oxidase, flavonoid 


\section{Pendahuluan}

Penanganan hiperurisemia biasanya dimulai dengan perubahan gaya hidup yaitu membatasi asupan makanan yang mengandung purin tinggi. Salah satu farmakoterapinya menggunakan allopurinol yang bekerja sebagai inhibitor enzim xanthin oksidase yang mengambat produksi asam urat dan sintesis purin. Allopurinol tidak dianjurkan memulai terapinya pada saat ada serangan hiperurisemia akut, tapi bisa diberikan dengan kolsikin atau OAINS. Penggunaannya seringkali dibatasi oleh efek samping yang ditimbulkan bila digunakan dalam jangka panjang seperti demam, reaksi alergi, nekrosis hati, ruam kulit, dan nefropati (Fitriani et al., 2017; Perhimpunan_Reumatologi_Indonesia, 2018; Tsuchida, 2002). Beberapa suku Asteraceae memiliki aktivitas sebagai antihiperurisemia, salah satunya adalah tanaman tapak liman (E. scaber) karena adanya senyawa yang terkandung yaitu golongan flavonoid yang memiliki mekanisme kerja sebagai inhibitor enzim xanthin oksidase (Musdja et al., 2019; Sutema, 2017). Selain flavonoid, tapak liman juga mengandung metabolit sekunder yang lain, yaitu tanin, saponin, dan triterpenoid/steroid (Nasution et al., 2021). Tanaman tapak liman (E. scaber) selain memiliki aktivitas sebagai antihiperurisemia, juga terbukti berkhasiat sebagai antiinflamasi, antibakteri, antivirus, diuretik, sitotoksik, dan hepatoprotektif (Harmanto et al., 2019). Maka dalam pembuatan Literature Review Article ini dipilih tanaman tapak liman sebagai antihiperurisemia berdasarkan kandungan senyawa aktifnya, karena masih banyak masyarakat yang belum tahu manfaat atau aktivitasnya sebagai antihiperurisemia tanaman tapak liman sebenarnya banyak dijumpai di lingkungan masyarakat sekitar.

\section{Metode}

Penelitian ini merupakan penelitian kualitatif menggunakan Literature Review Article (LRA) untuk mengetahui potensi senyawa aktif tanaman tapak liman (E. scaber) sebagai antihiperurisemia. Proses pencarian literatur dilakukan dengan menggunakan data yang dikumpulkan melalui instrumen pencarian online terbitan nasional ataupun internasional, dalam database elektronik seperti Google Shcolar, PubMed, Researchgate dan Science direct dengan menggunakan kata kunci yang berkaitan dengan topik penelitian, yaitu "Elephantopus scaber, antihiperurisemia, tapak liman, xantin oksidase, flavonoid". Artikel atau jurnal literatur yang sudah didapatkan, kemudian disesuaikan dengan kriteria inklusi yaitu artikel 10 tahun terakhir dari database Google Scholar, PubMed, ResearchGate dan Science direct dan kriteria eksklusi yaitu literature yang tidak sesuai topik dan selanjutnya dilakukan review. 


\section{Hasil dan pembahasan}

Artikel yang digunakan merupakan artikel hasil penelitian (original research) sesuai dengan kata kunci dan merupakan artikel 10 tahun terakhir dari database Google Shcolar, PubMed, ResearchGate dan Science direct. Tanaman tapak liman mengandung senyawa flavonoid yang berpotensi sebagai antihiperurisemia melalui mekanisme inhibitor xanthine oxidase. Berdasarkan hasil pencarian literatur, berikut beberapa senyawa aktif flavonoid yang berpotensi sebagai antihiperurisema dirangkum dalam tabel 1 dibawah ini:

Tabel 1. Senyawa aktif dan mekanisme kerja antihiperurisemia

\begin{tabular}{|c|c|c|c|c|}
\hline $\begin{array}{c}\text { Senyawa } \\
\text { aktif }\end{array}$ & Struktur kimia & $\begin{array}{l}\text { Desain } \\
\text { studi }\end{array}$ & Dosis/IC 50 & Referensi \\
\hline Luteolin & & $\begin{array}{l}\text { In vivo dan } \\
\text { in vitro }\end{array}$ & $\begin{array}{ll}\text { - } & \text { Dosis } 50 \mathrm{mg} / \mathrm{kg} . \\
\text { - } & \mathrm{IC}_{50} 4,79 \mu \mathrm{M} .\end{array}$ & $\begin{array}{l}\text { (Lodhi et al., 2020; Yan et } \\
\text { al., 2013) }\end{array}$ \\
\hline Quersetin & & $\begin{array}{l}\text { In vivo dan } \\
\text { in vitro }\end{array}$ & $\begin{array}{l}\text { - Dosis } 100 \text { dan } \\
200 \mathrm{mg} / \mathrm{kg} . \\
\text { - } \mathrm{IC}_{50} 2,74 \mu \mathrm{mol} \\
\mathrm{L}^{-1}\end{array}$ & $\begin{array}{l}\text { (Huang et al., 2011; Zhang } \\
\text { et al., 2018) }\end{array}$ \\
\hline Rutin & & In vivo & $\begin{array}{l}\text { - Dosis } 150 \text { dan } \\
300 \mathrm{mg} / \mathrm{kg} \\
\text { - Dosis } 25 \text { dan } 50 \\
\text { mg/kg }\end{array}$ & $\begin{array}{l}\text { (Chen et al., 2013; Huang } \\
\text { et al., 2011) }\end{array}$ \\
\hline $\begin{array}{l}\text { Luteolin-7- } \\
\text { glukosida }\end{array}$ & & In vitro & $-\mathrm{IC}_{50} 23,61 \mu \mathrm{M}$ & (Song et al., 2014) \\
\hline
\end{tabular}

Hasil dari penelusuran artikel menunjukkan bahwa tanaman tapak liman (E. scaber) berpotensi sebagai antihiperurisemia karena adanya kandungan senyawa golongan flavonoid yaitu luteolin, luteolin-7-glukosida, quersetin dan rutin yang terlihat dari beberapa penelitian yang telah dilakukan oleh peneliti. Dari penelitian sebelumnya dilaporkan bahwa flavonoid berpotensi menurunkan kadar asam urat dalam darah dengan cara menghambat aktivitas xantin oksidase. Pada penelitian yang dilakukan Musdja et al., ( 2019), bahwa tapak liman pada dosis $350 \mathrm{mg} / 200 \mathrm{~g}$ BB dapat menurunkan kadar asma urat dengan presentase tertinggi yaitu 43\% (Musdja et al., 2019). 
Penelitian lainnya juga melaporkan bahwa tanaman tapak liman dapat menghambat aktivitas enzim xantin oksidase yang diuji secara in vitro pada nilai $\mathrm{IC}_{50}$ sebesar 0,85-4,19 $\mu \mathrm{M}$ (Zhao et al., 2020).

Luteolin (3',4',5,7-tetrahidroksiflavon) merupakan senyawa kimia golongan flavonoid yang termasuk dalam subkelas flavon. Luteolin memiliki struktur C6-C3-C6, memiliki dua cincin benzena, cincin ketiga yang mengandung oksigen, dan ikatan rangkap karbon yang merupakan struktur penting terkait dengan aktivitas biokimia dan biologisnya. Luteolin stabil terhadap panas. Lodhi et al., (2020), meneliti bahwa luteolin dapat menurunkan kadar asam urat yang signifikan dengan dosis $50 \mathrm{mg} / \mathrm{kg}$ dengan adanya edema pada kaki tikus yang diinduksi kristal MSU (Lodhi et al., 2020). Penelitian sebelumnya juga melaporkan, bahwa luteolin dapat menghambat aktivitas enzim xantin oksidase secara signifikan pada nilai $\mathrm{IC}_{50}$ sebesar $4,79 \mu \mathrm{M}$ dengan mengukur pembentukan asam urat menggunakan spektrofotometri secara kontinyu pada panjang gelombang $290 \mathrm{~nm}$ dengan substrat xantin (Yan et al., 2013).

Senyawa quersetin dikategorikan sebagai flavonol yang merupakan salah satu subkelas dari flavonoid. Nama IUPAC untuk quersetin adalah 3,3',4',5,7-pentahidroksiflavon, dimana quersetin memiliki gugus $\mathrm{OH}$ yang menempel pada posisi 3,5,7,3', dan 4'. Quersetin adalah aglikon, tidak memiliki gula yang melekat. Berbentuk kristal jarum kuning yang sepenuhnya tidak larut dalam air dingin, kurang larut dalam air panas, tetapi cukup larut dalam alkohol dan lipid (Li et al., 2017). Yuan et al., (2019) meneliti bahwa quersetin memiliki aktivitas penghambatan enzim xantin oksidase yang diuji secra in vitro menggunakan spektrometer UV-Vis pada absorbansi $295 \mathrm{~nm}$ dengan mendapatkan nilai $\mathrm{IC}_{50} 0,0001 \mu_{\mathrm{molL}}^{-1}$ (Yuan et al., 2019). Penelitian sebelumnya juga menyatakan bahwa quersetin secara signifikan dapat menghambat pembentukan asam urat yang dikatalisis oleh xantin oksidase dengan melakukan pengujian secara in vitro dengan didapatkan

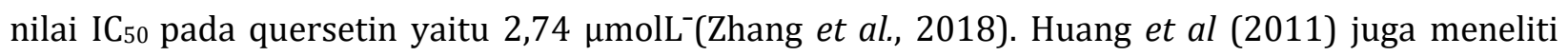
senyawa quersetin secara in vivo, pada dosis 100 dan $200 \mathrm{mg} / \mathrm{kg}$ quersetin dapat menghambat aktivitas xantin oksidase hati secara signifikan (Huang et al., 2011) .

Rutin (quersetin-3-0-rutinosida) adalah salah satu senyawa fenolik paling populer yang ditemukan di berbagai spesies tanaman (Dawidowicz et al., 2016). Rutin mempunyai rumus molekul $\mathrm{C}_{27} \mathrm{H}_{30} \mathrm{O}_{16} .3 \mathrm{H}_{2} \mathrm{O}$ dengan berat molekul sebesar 664,59. Rutin adalah suatu glikosida yang merupakan hasil kondensasi aglikon quersetin dengan gula rutinosa. Rutin merupakan bioflavonoid kapiler yang dapat berinteraksi dengan beberapa jenis metabolit dan sistem enzim sehingga memberikan efek terhadap sistem vaskular. Rutin juga dapat digunakan untuk menyembuhkan berbagai penyakit, seperti hipertensi, pendarahan yang bersifat keturunan seperti 
hemofilia, sakit kepala, dan pendarahan gusi. Chen et al., (2013) menyatakan bahwa senyawa rutin (quersetin-3-0-rutinosida) dapat menurunkan kadar asam urat dan kadar serum kereatin pada dosis 25 dan $50 \mathrm{mg} / \mathrm{kg}$, yang dilakukan menggunakan hewan uji tikus yang telah diinduksi oleh kalium oksonat (Chen et al., 2013). Penelitian sebelumnya juga menyatakan bahwa rutin dapat menghambat aktivitas xantin oksidase pada dosis 150 dan 300 mg/kg (Huang et al., 2011).

Luteolin-7-glukosida adalah komponen aktif utama luteolin. Senyawa ini memiliki beberapa bioaktif seperti anti-tumor,antioksidan, antiinflamasi, dan perlindungan sistem saraf. Luteolin-7glukosida merupakan senyawa golongan flavonoid yang termasuk kedalam subkelas flavon(Chen et al., 2018). Hasil penelitian yang dilakukan oleh Song et al., (2014), menyatakan bahwa luteolin-7glukosida dapat menghambat aktivitas xantin oksidase dengan nilai IC $_{50}$ sebesar 23,61 $\mu \mathrm{M}$ yang dilakukan dengan menggunakan spektofotometri pada absorbansi $290 \mathrm{~nm}$ (Song et al., 2014).

\section{Kesimpulan}

Senyawa flavonoid tanaman tapak liman (E. scaber) yang berpotensi sebagai antihiperurisemia yaitu senyawa luteolin, luteolin-7-glukosida, quersetin, dan rutin.

\section{Daftar pustaka}

Chen, S., Yang, B., Xu, Y., Rong, Y., \& Qiu, Y. (2018). Protection of Luteolin-7-O-glucoside Against Apoptosis Induced by Bypoxia/Reoxygenation through the MAPK Pathways in H9c2 Cells. Molecular medicine reports, 17(5), 7156-7162. doi:10.3892/mmr.2018.8774

Chen, Y. S., Hu, Q. H., Zhang, X., Zhu, Q., \& Kong, L. D. (2013). Beneficial Effect of Rutin on Oxonateinduced Hyperuricemia and Renal Dysfunction in Mice. Pharmacology, 92(1-2), 75-83. doi:10.1159/000351703

Dawidowicz, A. L., Bernacik, K., \& Typek, R. (2016). Rutin Transformation during Its Analysis Involving Extraction Process for Sample Preparation. Food Anal Methods, 9, 213-224. doi: https://doi.org/10.1007/s12161-015-0170-2

Fitriani, U., Ardiyanto, D., \& Mana, T. A. (2017). Evaluasi Keamanan dan Manfaat Ramuan Jamu untuk Hiperurisemia Buletin Penelitian Kesehatan, 45(4), 227-232. doi: https://doi.org/10.22435/bpk.v45i4.6855.227-232

Harmanto, N., Nando, A., \& Tjahjadi, V. K. (2019). Efek Segera Jamu X terhadap Kadar Asam Urat Darah Relawan Hiperurisemia. CDK-273, 46 (2), 87-89. doi:http://www.cdkjournal.com

Huang, J., Wang, S., Zhu, M., Chen, J., \& Zhu, X. (2011). Effects of Genistein, Apigenin, Quercetin, Rutin and Astilbin on Serum Uric Acid Levels and Anthine Oxidase Activities in Normal and Hyperuricemic Mice. Food Chem Toxicol, 49(9), 1943-1947. doi:10.1016/j.fct.2011.04.029

Li, F., Jiang, T., Li, Q., \& Ling, X. (2017). Camptothecin (CPT) and Its Derivatives are Known to Target Topoisomerase I (Top1) as Their Mechanism of Action: Did We Miss something in CPT Analogue Molecular Targets for Treating Human Disease such As Cancer? Am J Cancer Res, 7(12), 2350-2394.

Lodhi, S., Vadnere, G. P., Patil, K. D., \& Patil, T. P. (2020). Protective Effects of Luteolin on Injury Induced Inflammation through Reduction of Issue Uric Acid and Pro-inflammatory Cytokines in Rats. J Tradit Complement Med, 10(1), 60-69. doi:10.1016/j.jtcme.2019.02.004

Seminar Nasional Asosiasi Perguruan Tinggi Farmasi Indonesia (APTFI) III-Tantangan Pandemik (covid-19) dalam pembelajaran dan penelitian kefarmasian 16-20 Agustus 2021 (Virtual Conference) 
Musdja, M. Y., Azter, A. A., \& Musir, A. ( 2019). The Effect of Ethanol Extract of Elephantopus scaber Linn in Decreasing Blood Uric Acid Levels of Hyperuricemic Male Rats. European Journal of Medicinal Plants, 28(4), 1-9. doi:https://doi.org/10.9734/ejmp/2019/v28i430140

Nasution, S. W., Lubis, N., Zendrato, B. C. L., \& Silaban, S. R. (2021). Uji Aktivitas Antibakteri Ekstrak Etanol Daun Tapak Liman (Elephantopus Scaber L) terhadap Bakteri Shigella dysenteriae dengan Metode Difusi Cakram. Jurnal Biospecies, 14(1), 18-23. doi:https://onlinejournal.unja.ac.id

Perhimpunan_Reumatologi_Indonesia. (2018). Pedoman Diagnosis dan Pengelolaan Gout. In: Perhimpunan Reumatologi Indonesia.

Song, H. P., Zhang, H., Fu, Y., Mo, H. Y., Zhang, M., Chen, J., \& Li, P. (2014). Screening for Selective Inhibitors of Xanthine Oxidase from Flos Chrysanthemum using Ultrafiltration LC-MS Combined with Enzyme Channel Blocking. J Chromatogr B Analyt Technol Biomed Life Sci, 961, 56-61. doi:10.1016/j.jchromb.2014.05.001

Sutema, I. A. M. P. (2017). Efek Analgesik Kombinasi Ekstrak Herba Tapak Liman (Elephantopus Scaber L ) dan Rumput Mutiara ( Hedyotis Corymbosa L ) pada Mencit Jantan dengan Metode Pododolorimetri. Medicamento, 3(2), 126-130. doi:https://doi.org/10.36733/medicamento.v3i2.1036

Tsuchida, S. (2002). Test and Repair of Non-volatile Commodity and Embedded Memories. Paper presented at the Proceedings. International Test Conference.

Yan, J., Zhang, G., Hu, Y., \& Ma, Y. (2013). Effect of Luteolin on Xanthine Oxidase: Inhibition Kinetics and Interaction Mechanism Merging with Docking Simulation. Food Chem, 141(4), 37663773. doi:10.1016/j.foodchem.2013.06.092

Yuan, M., Liu, Y., Xiao, A., Leng, J., Liao, L., Ma, L., \& Liu, L. (2019). The Interaction of Dietary Flavonoids with Xanthine Oxidase: In vitro: Molecular Property-binding Affinity Relationship Aspects. RSC Advances, 9(19), 10781-10788. doi:10.1039/C8RA09926J

Zhang, C., Wang, R., Zhang, G., \& Gong, D. (2018). Mechanistic Insights into the Inhibition of Quercetin on Xanthine Oxidase. Int $J$ Biol Macromol, 112, 405-412. doi:10.1016/j.ijbiomac.2018.01.190

Zhao, J., Huang, L., Sun, C., Zhao, D., \& Tang, H. (2020). Studies on the Structure-activity Relationship and Interaction Mechanism of Flavonoids and Xanthine Oxidase through Enzyme Kinetics, Spectroscopy Methods and Molecular Simulations. Food Chem, 323. doi:10.1016/j.foodchem.2020.126807 